\title{
Electrocatalytic Oxidation of Dopamine, Ascorbic Acid and Uric Acid at Poly-2,6-Diaminopyridine on the Surface of Carbon Nanotubes/GC Electrodes
}

\author{
Mohammad Ali Kamyabi* and Mohammad Ali Shafiee \\ Department of Chemistry, Zanjan University, PO Box 45195-313, Zanjan, Islamic Republic of Iran
}

\begin{abstract}
A preparação e aplicação de poli-(2,6-diaminopiridina) sobre a superfície de um eletrodo de carbono vítreo (GCE) modificado com nanotubos de carbono de paredes múltiplas (CNTs) são descritas. Voltametria cíclica foi usada na síntese eletroquímica e na caracterização dos polímeros depositados sobre GCE. O eletrodo modificado mostra um efeito sinérgico das propriedades eletrocatalíticas e a elevada superfície ativa de ambos, polímero condutor e nanotubos de carbono, dando origem a uma melhora notável da oxidação eletrocatalítica de ácido ascórbico (AA), dopamina (DA) e ácido úrico (UA) com respeito a eletrodos modificados com polímero e eletrodos modificados com CNTs. Este tipo de eletrodo modificado mostra uma excelente atividade eletrocatalítica para a oxidação de AA, DA e UA dentro de um intervalo linear de $2,70 \times 10^{-5}-1,83 \times 10^{-3}, 8,33 \times 10^{-7}-1,00 \times 10^{-5}$ e $4,16 \times 10^{-6}-2,25 \times 10^{-4} \mathrm{~mol} \mathrm{~L}^{-1}$, respectivamente, em pH 8.0 (solução padrão de fosfato). A mistura ternária que contém AA, DA e UA pode ser muito bem separada uma da outra a uma velocidade de varredura de $100 \mathrm{mV} \mathrm{s}^{-1}$ com uma diferença de potencial de 184, 147 e $321 \mathrm{mV}$ em voltametria de pulso diferencial (DPV) entre AA e DA, DA e UA, e AA e UA, respectivamente. Esta abordagem é tão fácil que pode ser usada para detectar seletivamente DA, AA e UA na presença uma das outras e também em algumas amostras reais.
\end{abstract}

The preparation and application of poly-(2,6-diaminopyridine) on the surface of a glassy carbon electrode (GCE) modified with multi-walled carbon nanotubes (CNTs) are reported. Cyclic voltammetry was used for both the electrochemical synthesis and characterization of the polymers deposited on GCE. The modified electrode shows a synergic effect of the electrocatalytic properties and high active surface area of both the conducting polymer and carbon nanotubes, giving rise to a remarkable improvement of electrocatalytic oxidation of ascorbic acid (AA), dopamine (DA) and uric acid (UA) with respect to polymer-modified electrodes and CNTs-modified electrodes. This kind of modified electrode shows and excellent electrocatalytic activity towards the oxidation of AA, DA and UA within the linear range of $2.70 \times 10^{-5}-1.83 \times 10^{-3}$, $8.33 \times 10^{-7}-1.00 \times 10^{-5}$ and $4.16 \times 10^{-6}-2.25 \times 10^{-4} \mathrm{~mol} \mathrm{~L}^{-1}$, respectively, in $\mathrm{pH} 8.0$ (phosphate buffer solution). The ternary mixture, which contains AA, DA and UA, can be well separated from each other at a scan rate of $100 \mathrm{mV} \mathrm{s}^{-1}$ with a potential difference of 184,147 and $321 \mathrm{mV}$ in differential pulse voltammetry (DPV) between AA and DA, DA and UA, and AA and UA, respectively. This approach is so simple and easy that can be used to selectively detect DA, AA and UA in the presence of each other and also in some real samples.

Keywords: 2,6-diaminopyridine, electropolymerized film, ascorbic acid, dopamine, uric acid

\section{Introduction}

Today, one of the main challenges is the development of methods to perform clinical analyses that are rapid in situ analyses. These methods must be sensitive and accurate, and able to determine various substances with different properties in real-life samples. Electrochemical

*e-mail: makamyabi@gmail.com sensors for the measurement of analytes of interest in clinical chemistry are ideally suited for these new applications due to their high sensitivity and selectivity, portable field-based size, rapid response and low-cost. ${ }^{1}$

During recent years, great efforts have been devoted to the development of electrochemical sensors with electrosynthesized polymeric film electrodes. Modified electrodes prepared by electropolymerization have obvious advantages in the detection of analytes. For example, it 
can accelerate transmission of electrons on the surface of electrode, it has high selectivity and sensitivity due to the film homogeneity in electrochemical deposition, strong adherence to the electrode surface and large surface area. ${ }^{2,3}$ Unlike conventional immobilization strategies for biosensors, electropolymerization has no limit in terms of the geometry and area of the electrode, and offers advantages with respect to thickness control, reproducibility and uniformity of the polymer film on the electrode surfaces with more complex geometries. ${ }^{4}$ In addition, electropolymerization permits simple electrode regeneration and can be easily extended to the production of microbiosensors. Many studies have indicated that polymer film modified electrodes show an enhanced response for the determination of various important biological and clinical species. 5

Electropolymerization of conducting polymers, such as polypyrrole (PPy), polyaniline, polyacetylene, polyindole, polythionine and polythiophene, has been studied extensively for the development of biosensors. ${ }^{6-8}$ These polymers offer great advantages due to their very good conducting and mechanical properties and good adhesion to the electrode substrate. However, it is of interest to extend such studies to non-conducting polymers like polyphenol, $\operatorname{poly}(o-$ phenylenediamine), poly(dichlorophenolindophenol) and overoxidized polypyrrole which have specific advantages for biosensor construction and electrocatalytic reactions. ${ }^{9-18}$ The non-conducting polymers provide very thin films due to their self-limiting growth, and hence the biosensors based on them have fast response. In addition, the permselectivity of the non-conducting films confer them improved biosensor selectivity and anti-fouling properties. Non-conducting membranes from polyphenylenediamines (PPDs) have been of particular interest because of their thin, dense films leading to both fast response and high $\mathrm{H}_{2} \mathrm{O}_{2}$ or $\mathrm{O}_{2}$ selectivity. Jang et al. ${ }^{19}$ reported the electropolymerization mechanism for poly(1,2-diaminobenzene), and the film of electropolymerized poly $(1,2-\mathrm{DAB})$ has been analyzed by an impedimetric technique. ${ }^{20} \mathrm{Also}$, enzyme glucose oxidase (GOx) has been entrapped in a poly(1,2-DAB) film through the polymerization of 1,2-DAB on platinum-coated carbon fibers. ${ }^{21-23}$

In this work, an electropolymerized film of 2,6-diaminopyridine (2,6-DAP) was prepared on the surface of a GC electrode in $0.10 \mathrm{~mol} \mathrm{~L}^{-1} \mathrm{HCl}$ in methanol by cyclic voltammetry $(\mathrm{CV})$. The poly(2,6-DAP) on the surface of GCE showed excellent catalytic activity toward oxidation of some biological compounds and conspicuously enhanced the redox peak currents. The ternary mixture, which contains ascorbic acid (AA), dopamine (DA) and uric acid (UA), can be well separated from each other at the surface of this modified electrode. The separations of the oxidation peak potentials of AA-DA and DA-UA were over more than 184 and $147 \mathrm{mV}$, respectively. Using differential pulse voltammetry (DPV) technique, the calibration curves for AA, DA and UA were obtained over a wide range $\left(2.70 \times 10^{-5}-1.83 \times 10^{-3} \mathrm{~mol} \mathrm{~L}^{-1}\right.$ for AA, $8.33 \times 10^{-7}-1.00 \times 10^{-5} \mathrm{~mol} \mathrm{~L}^{-1}$ for DA and $4.16 \times 10^{-6}-2.25 \times 10^{-4} \mathrm{~mol} \mathrm{~L}^{-1}$ for UA at the poly $(2,6-\mathrm{DAP})$ modified GCE). The theoretical limits of detection defined as $3 \sigma$ of the proposed method for AA, DA and UA were $5.00 \times 10^{-6}, 4.16 \times 10^{-8}$ and $7.10 \times 10^{-7} \mathrm{~mol} \mathrm{~L}^{-1}$, respectively. These results are somewhat similar (or worse) performances (in some cases) or superior ones (in most cases) than the previously reported modified electrodes in literatures. ${ }^{24-35}$

For the first time, the electropolymerization of 2,6-diaminopyridine was studied by Morea et al..$^{36}$ in acetonitrile solvent at a platinum electrode that led to the formation of two different films depending on the deposition potential. Their results revealed an ECE mechanism (electron transfer, chemical reaction, electron transfer) operating for film I formation and provided evidence for nucleation and growth in film II deposition. ${ }^{36}$ In the present work, the electropolymerization of 2,6-diaminopyridine is reported on the surface of a GC electrode in $0.10 \mathrm{~mol} \mathrm{~L}^{-1}$ $\mathrm{HCl}$ in methanol. This film formation is different from the previously reported,$^{36}$ and thus, the present study provides a novel method for selective and sensitive detection of DA, AA and UA in the presence of the other two species.

\section{Experimental}

\section{Reagents and solutions}

All chemicals were of analytical reagent grade (from Merck or Sigma) unless otherwise specified and were used as received without further purification. Triply distilled water was used to prepare buffer and reagent solutions. The supporting electrolyte used in all the experiments was $0.1 \mathrm{~mol} \mathrm{~L}^{-1}$ phosphate buffer solutions (PBS).

\section{Apparatus}

Voltammetric experiments were performed using Metrohm Computrace Voltammetric Analyzer model 757 VA. A conventional three-electrode system was used with a bare or chemically modified GCE as working electrode, reference electrode $\mathrm{Ag} / \mathrm{AgCl}, \mathrm{KCl} 3 \mathrm{~mol} \mathrm{~L}^{-1}$, and a platinum wire counter electrode. A digital $\mathrm{pH} / \mathrm{mV}$ meter model 780 Metrohm was applied for the preparation of the buffer solution. All experiments were performed at an ambient temperature of $25 \pm 2{ }^{\circ} \mathrm{C}$. 


\section{Preparation of the modified electrode}

The glassy carbon electrode ( $2 \mathrm{~mm}$ diameter) was carefully polished with alumina powders $(1.0,0.3$ and $0.05 \mu \mathrm{m})$ on polishing cloth. The electrode was placed in ethanol container and it was used bath ultrasonic cleaner in order to remove adsorbed particles. Then, 15 cycle scans were carried out in the potential range of -2.0 to $+2.0 \mathrm{~V} v s$. reference electrode in a solution of $1.0 \mathrm{~mol} \mathrm{~L}^{-1}$ sulfuric acid $\left(\mathrm{H}_{2} \mathrm{SO}_{4}\right),{ }^{35,37}$ this process was used to remove any impurities of the electrode surface. Finally, the electrode thoroughly washed with triply distilled water, and for drying, it was heated for $5 \mathrm{~min}$ at $50{ }^{\circ} \mathrm{C}$ in oven. Multi-walled carbon nanotubes (MWNTs) (10 mg) were dispersed in $10 \mathrm{~mL}$ dimethyl sulfoxide (DMSO) by ultrasonic stirring for about 30 min to give a black suspension of $1 \mathrm{mg} \mathrm{mL}^{-1}$. The MWNT modified electrode was prepared by casting $10 \mu \mathrm{L}$ of the MWNT suspension on the surface of GC electrode, which was dried in air for $24 \mathrm{~h}$ at room temperature. When the DMSO was volatilized, a MWNT film was formed. The surface modification of the MWNTs/GCE was performed in two steps:

(i) The poly(2,6-DAP) films were formed on the electrode surfaces by continuous potential cycling between -0.3 and $1.2 \mathrm{~V}$ at $50 \mathrm{mV} \mathrm{s}^{-1}$ in $0.10 \mathrm{~mol} \mathrm{~L}^{-1} \mathrm{HCl}$ containing $4.0 \mathrm{mmol} \mathrm{L}^{-1}$ 2,6-DAP, (total volume of $10 \mathrm{~mL}$ ). Typically, 20 cycles were employed (although other cycle numbers were also studied).

(ii) In the second step, the poly(2,6-DAP) film on the GC electrode was converted to a conducting polymer by cycling the potential scan in $0.01 \mathrm{~mol} \mathrm{~L}^{-1} \mathrm{NaOH}$ solution at the scan rate of $50 \mathrm{mV} \mathrm{s}^{-1}$ for 10 times.

The surface area of the modified electrode (poly 2,6 DAP)/MWNTs/GCE) was $1.053 \pm 0.006 \mathrm{~cm}^{2}$ whereas for MWNTs/GCE $0.821 \pm 0.005 \mathrm{~cm}^{2}$, which were evaluated from cyclic voltammetry experiments. After surface modification of the GCE, the modified electrode was rinsed with distilled water and stored in triply distilled water for use. Solutions were purged with high purity nitrogen gas for at least $10 \mathrm{~min}$ before electrochemical measurements.

\section{Results and Discussion}

\section{Electropolymerization of 2,6-DAP and its electrochemical properties}

Because of difficulties related to the low solubility of 2,6-DAP, several aqueous media with different $\mathrm{pH}$ values were used for the electropolymerization of 2,6-DAP at the MWNTs/GCE. The final choice of medium was $0.10 \mathrm{~mol} \mathrm{~L}^{-1} \mathrm{HCl}$ in methanol (concentrations of $\mathrm{HCl}$ were examined from 0.01 to $1.00 \mathrm{~mol} \mathrm{~L}^{-1}$, and $0.10 \mathrm{~mol} \mathrm{~L}^{-1}$ was used as optimum to give good solubility of 2,6-DAP). The continuous cyclic voltammograms that were recorded used GCE dipped in a mixture containing $4.0 \mathrm{mmol} \mathrm{L}^{-1}$ of 2,6-DAP and $0.1 \mathrm{~mol} \mathrm{~L}^{-1} \mathrm{HCl}$ under deaerated conditions. The effects of various factors on the poly(2,6-DAP) film formation on the surface of the MWNTs/GCE (such as the amount of monomer scan rate, number of scan, potential window, $\mathrm{pH}$ and also the conditions of the alkaline treatment) were evaluated according to the variation of the peak current of the cyclic voltammograms obtained for the modified electrode.

Figure 1 displays the CVs of 2,6-DAP electropolymerization over the range of -0.3 to $1.2 \mathrm{~V}$ at $50 \mathrm{mV} \mathrm{s}^{-1}$ for 20 cycles. The forward scan of the first cycle revealed the presence of an irreversible oxidation and reduction peak of the monomer (Figure 1, first cycle, $\mathrm{O}_{1}$ and $\mathrm{R}_{1}$ peaks) with peak potentials at about 1.01 and $0.68 \mathrm{~V}$, respectively ( $v \mathrm{~s} . \mathrm{Ag} / \mathrm{AgCl}$ ). In the subsequent cycles, the oxidation current decreased at $1.01 \mathrm{~V}$ with a simultaneous appearance of a pair of redox peaks at about $300 / 390 \mathrm{mV}$ due to the formation of poly(2,6-DAP) film. This clearly shows the oxidation of the monomer 2,6-DAP and the formation of poly(2,6-DAP) film on the surface of the MWNTs/GCE. The peak-to-peak separation $\left(\Delta \mathrm{E}_{\mathrm{p}}=\mathrm{E}_{\mathrm{pa}}-\mathrm{E}_{\mathrm{pc}}\right.$ of the pair redox peaks at about $300 / 390 \mathrm{mV}$ ) was bigger with increasing the number of cycles $(90.0 \mathrm{mV}$ in the second cycle and $200 \mathrm{mV}$ in the last cycle). This fact suggests that the nonconductive polymer film was formed on the

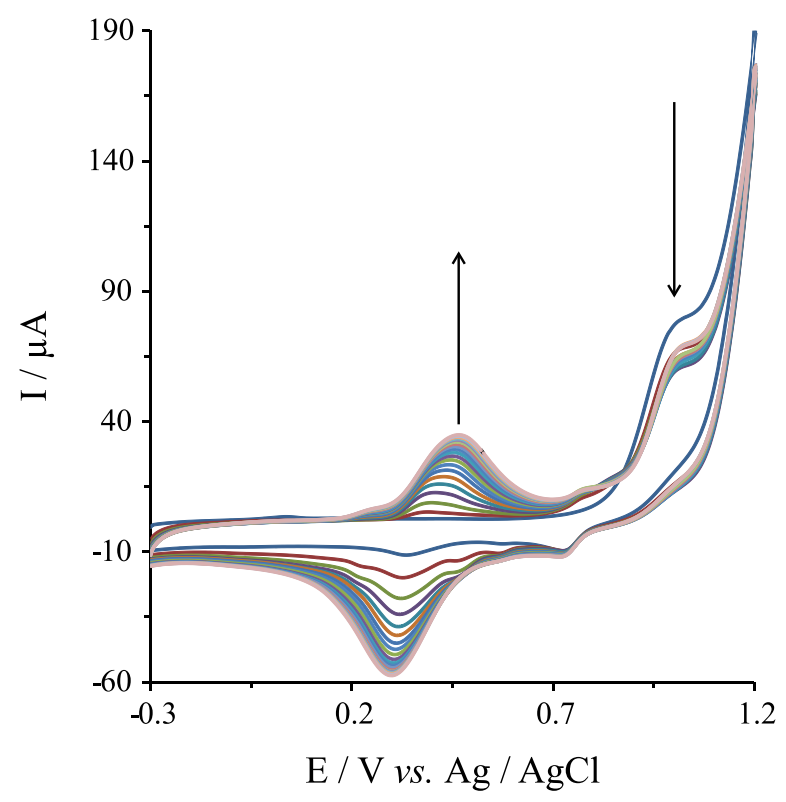

Figure 1. Cyclic voltammograms recorded during growth of poly(2,6-DAP) films on the $\mathrm{GC}$ electrode in $0.1 \mathrm{~mol} \mathrm{~L}^{-1} \mathrm{HCl}$ solution containing $0.04 \mathrm{~mol} \mathrm{~L}^{-1}$ of 2,6-DAP, between -0.3 and $1.2 \mathrm{~V}$ vs. $\mathrm{Ag} / \mathrm{AgCl}$, potential scan rate of $50 \mathrm{mV} \mathrm{s}^{-1}$. 
(a)<smiles>Nc1cccc(N)n1</smiles><smiles>NC1=NC(=Nc2cccc(N)n2)C=CC1</smiles>

(c)<smiles>NC1=NC(=Nc2cccc(N)n2)C=CC1</smiles><smiles>CCN=C1C=CC(=Nc2cccc(NC)n2)N=C1NNc1cccc(NC)n1</smiles>

Scheme 1.

surface of GC electrode with increasing scan cycles. A similar peak was also seen for the electropolymerization of $o$-phenylenediamine $(o \mathrm{PD})^{38}$ and for 4-nitro1,2-phenylenediamine (4-NoPD). ${ }^{39}$

Scheme 1 represents the proposed mechanism for the formation of the active component during the electropolymerization. ${ }^{19,36,39}$ The polymerization mechanism may be described as follows: 2,6-DAP was first oxidized to free radical (Scheme 1a). The processes occurring after this first step may follow various paths, the coupling of such radicals may occur or the elimination of ammonia group during electrochemical oxidation may occur (Scheme 1b).$^{40}$ However, a possible structure for the film is shown in Scheme 1c. The suggestion of a structure for the film is beyond the scope of this work. In fact, several possible polymeric backbones may be considered. Moreover, since 2,6-DAP has two virtual reaction sites (i.e., two amino groups), cross-linking reactions may also take place. This obviously enlarges the number of structures that may describe the film.

The poly(2,6-DAP) is a non-conducting membrane and this modified electrode does not show any electrocatalytic activity in aqueous solution. However, several scan cycles of the poly(2,6-DAP) film modified GCE in an alkaline solution (alkaline treatment) can improve the conductivity and also the electrocatalytic acitivity of the modified electrode (Figure S1). The cyclic voltammogram of MWNTs/ GCE modified with poly(2,6-DAP) film (after alkaline treatment) shows a pair of reversible peaks in 0.1 PBS $\mathrm{pH} 8$ at formal potential of about $-80 \mathrm{mV}$ with $\Delta \mathrm{E}_{\mathrm{p}}$ about $60 \mathrm{mV}$ at scan rate of $100 \mathrm{mV} \mathrm{s}^{-1}$ in $\mathrm{PBS} \mathrm{pH} 8.0$ (Figure 2).

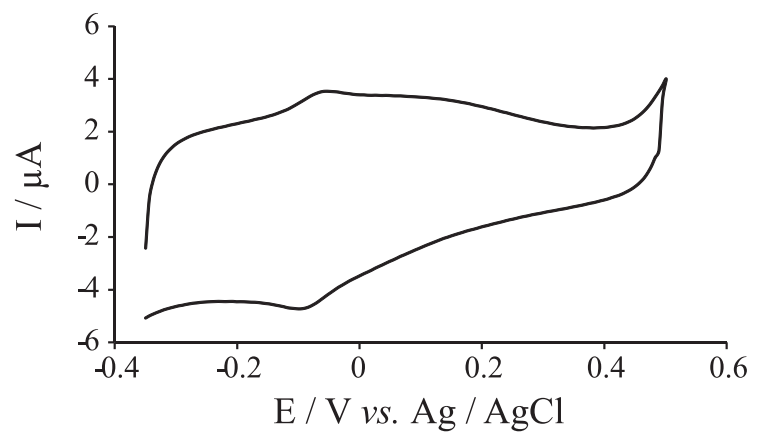

Figure 2. Cyclic voltammograms for the poly(2,6-DAP) film on the GC electrode in $0.1 \mathrm{~mol} \mathrm{~L}^{-1} \mathrm{PBS} \mathrm{pH}=8$, between -0.3 and $1.2 \mathrm{~V} v s . \mathrm{Ag} / \mathrm{AgCl}$, potential scan rate of $100 \mathrm{mV} \mathrm{s}^{-1}$.

The good conductivity and electrocatalytic activity of the modified electrode after an alkaline treatment may be due to the reduction of some of the $\mathrm{C}-\mathrm{N}$ bonds in the polymer and the rearrangement of the polymer. Similar behavior was also reported for poly $(o \mathrm{PD}) .{ }^{14,15,41} \mathrm{By}$ this alkaline treatment, the resulted conductive polymeric film shows a good electrocatalytic activity toward simultaneous detection of AA, DA and UA in the ternary mixture of them in $0.1 \mathrm{~mol} \mathrm{~L}^{-1}$ BPS, $\mathrm{pH} 8$.

The effect of the scan rate on cyclic voltammogram of the poly(2,6-DAP) electrode (after alkaline treatment) in 
the range of -0.3 to $0.5 \mathrm{~V}$ in the $0.1 \mathrm{~mol} \mathrm{~L}^{-1} \mathrm{PBS} \mathrm{pH} 8.0$ was also investigated (Figure S2a). The anodic and cathodic peak currents are directly proportional to the scan rate in the range below $500 \mathrm{mV} \mathrm{s}^{-1}$ (Figure S2b) with the linear equations: $\mathrm{I}_{\mathrm{pa}}(\mu \mathrm{A})=0.072 \vee\left(\mathrm{mV} \mathrm{s}^{-1}\right)-4.488(\mathrm{n}=10$, $\left.\mathrm{R}^{2}=0.995\right)$ and $\mathrm{I}_{\mathrm{pc}}(\mu \mathrm{A})=-0.077 v\left(\mathrm{mV} \mathrm{s}^{-1}\right)+5.213$ $\left(n=10, R^{2}=0.994\right)$, respectively. The ratio of the anodic to cathodic peak currents obtained at various scan rates was almost unity. The formal potential $\mathrm{E}^{\circ}=\left(\mathrm{E}_{\mathrm{pa}}+\mathrm{E}_{\mathrm{pc}}\right) / 2$ is almost independent of the potential scan rate for scan rates below $500 \mathrm{mV} \mathrm{s}^{-1}$, suggesting facile charge transfer kinetics over this range of scan rate.

The stability of the modified electrodes and the reproducibility of their electrochemical behavior were investigated by cyclic voltammetry after storing them in buffer solution $(\mathrm{pH} 8)$ for a long period of time and then recording the cyclic voltammograms. After immersing the modified electrodes for $24 \mathrm{~h}$, the currents and the potential response remained almost unchanged. The recorded cyclic voltammograms after two week storing under ambient conditions were reproducible and unchanged. In addition, the stability and reproducibility of the modified electrodes were examined by repetitive recording of the cyclic voltammograms in buffer solution ( $\mathrm{pH} \mathrm{8)}$. There was no change in the peak height and peak-to-peak separation after 50 cycles of repetitive cycling at scan rate of $100 \mathrm{mV} \mathrm{s}^{-1}$.

\section{Electrocatalytic activity of the modified GCE}

The catalytic oxidation of AA, DA and UA at the modified GCE was examined to evaluate the feasibility of using the modified electrode in electrocatalysis as well as in electroanalysis. In order to test the electrocatalytic activity of the modified electrodes, the cyclic voltammograms were obtained in the absence and presence of analytes in buffer solution.

The results obtained under optimum conditions $(\mathrm{pH}$ 8.0) show that electrooxidation of ascorbic acid on the surface of the modified electrode occurs at a potential about $373 \mathrm{mV}$, less positive than that of at a bare GCE. The irreversible oxidation of ascorbic acid in $\mathrm{pH} 8.0$ at a bare GCE occurs at $331 \mathrm{mV} v s . \mathrm{Ag} / \mathrm{AgCl}$ (Figure 3a), while its oxidation peak at the modified electrode becomes about $-0.042 \mathrm{mV} v s$. reference electrode (Figure $3 \mathrm{c}$ ). The great increment of the current is mainly ascribed to the higher electroactive surface area of the poly(2,6-DAP)/MWNTs/ GCE. The poly(2,6-DAP) modified MWNTs/GCE before alkaline treatment had no electrocatalytic activity towards the electrooxidation of AA.

MWNTs could increase the surface area of the electrode, so the background current of the modified electrode is
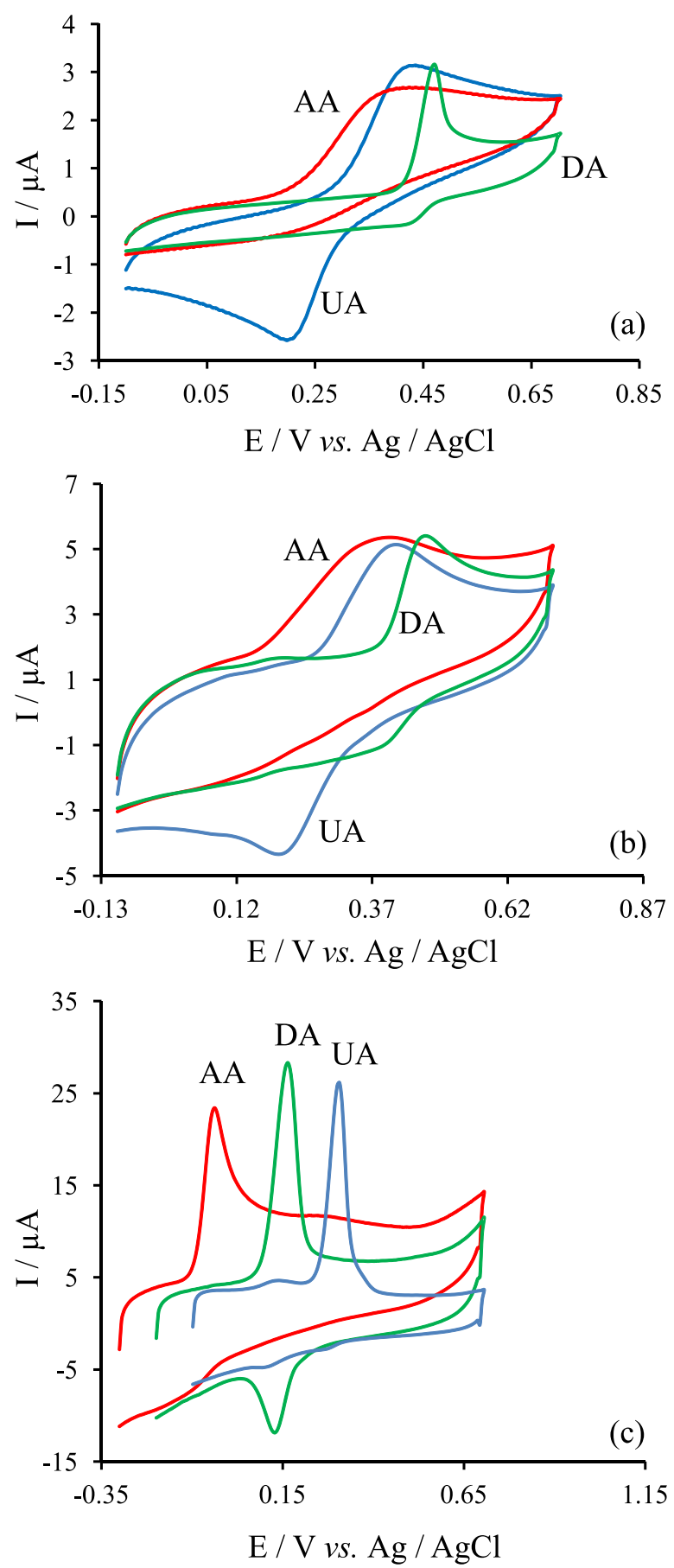

Figure 3. (a) Cyclic voltammograms of $0.5 \mathrm{mmol} \mathrm{L}^{-1}$ ascorbic acid, $0.1 \mathrm{mmol} \mathrm{L}^{-1}$ dopamine and $0.5 \mathrm{mmol} \mathrm{L}^{-1}$ uric acid on the bare GCE, (b) and (c) cyclic voltammograms of $0.8 \mathrm{mmol} \mathrm{L}^{-1}$ ascorbic acid, $8 \mu \mathrm{mol} \mathrm{L}{ }^{-1}$ dopamine and $30 \mu \mathrm{mol} \mathrm{L}^{-1}$ uric acid on the MWNTs/GCE and poly(2, 6-DAP)/MWNTs/GCE, respectively, in PBS pH 8.0, the scan rate of $100 \mathrm{mV} \mathrm{s}^{-1}$.

higher than that of the bare surface (Figure 3b). In fact, the MWNTs/GC electrode can increase the current of the electrooxidation of AA but had no effect on decreasing the over-voltage of the electrooxidation of AA and also for DA and UA. 
The oxidation of dopamine on the modified electrode is more reversible $\left(\Delta \mathrm{E}_{\mathrm{p}}=32 \mathrm{mV}\right)$. As can be seen in Figure $3 \mathrm{a}$, cyclic volammogram of dopamine in $\mathrm{pH} 8.0$ on the surface of a bare GC electrode showed a quasireversible behavior and the oxidation peak appeared at $411 \mathrm{mV} v$ s. Ag/ $\mathrm{AgCl}$. Whereas, its oxidation peak potential at the surface of the modified electrode was shifted to $170 \mathrm{mV}$ (Figure 3c). Also the oxidation of dopamine on the surface of poly(2,6-DAP) modified GCE before alkaline treatment is almost similar to a bare GCE.

The irreversible oxidation of uric acid in $\mathrm{pH} 8.0$ at a bare $\mathrm{GC}$ electrode occurs at $465 \mathrm{mV}$ vs. $\mathrm{Ag} / \mathrm{AgCl}$ (Figure 3a), while its oxidation peak at the modified electrode becomes about $307 \mathrm{mV} v$ s. reference electrode (Figure 3c). Again the poly(2,6-DAP) modified MWNTs/GC before alkaline treatment shows no catalytic effect on the electro-oxidation of uric acid.

The shift in potential values for oxidation of dopamine and uric acid at the surface of the modified GCE is smaller than that of ascorbic acid oxidation. Therefore, a separation of the oxidation peak potentials of dopamine, uric acid and ascorbic acid at the surface of the modified GCE occurred. Figure $3 \mathrm{c}$ shows that ascorbic acid, dopamine and uric acid are oxidized in $\mathrm{pH} 8.0$ on the modified GCE at different potentials ( $\mathrm{E}_{\mathrm{pa}}$ for oxidations of ascorbic acid are $52 \mathrm{mV}$ and for dopamine and uric acid 195 and $322 \mathrm{mV}$, respectively (vs. $\mathrm{Ag} / \mathrm{AgCl}$ ) with a suitable peak separation potentials which are about 143 and $127 \mathrm{mV}$ between DA-AA and DA-UA, respectively). For simultaneous determination of DA, AA and UA, differential pulse voltammetry (DPV) was carried out in the potential range of -100 to $400 \mathrm{mV}$ (Figure 4). Three well-defined peaks at about $-63,121$ and $258 \mathrm{mV}$ vs. $\mathrm{Ag} / \mathrm{AgCl}$ were observed, corresponding to the differential pulse voltammograms of AA, DA, and UA, respectively. The

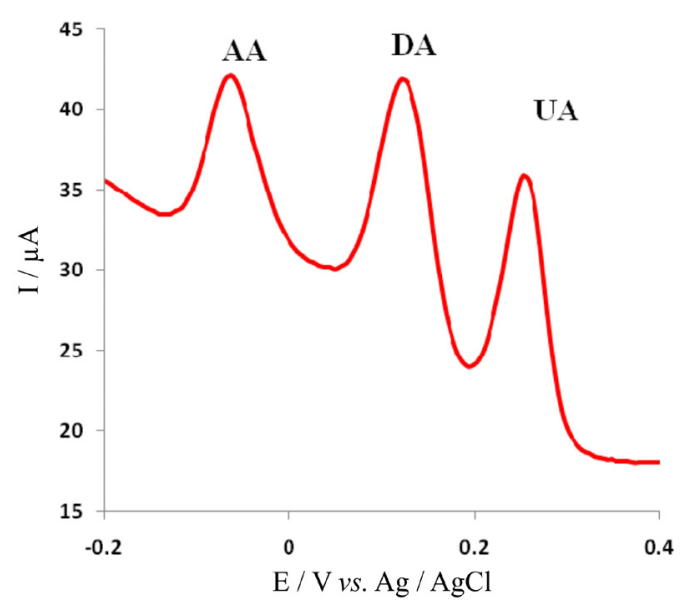

Figure 4. Differential pulse voltammograms of mixture of $0.8 \mathrm{mmol} \mathrm{L}^{-1}$ ascorbic acid, $8 \mu \mathrm{mol} \mathrm{L} \mathrm{L}^{-1}$ dopamine and $30 \mu \mathrm{mol} \mathrm{L} \mathrm{L}^{-1}$ uric acid on the modified GCE in PBS pH 8.0, the scan rate was $100 \mathrm{mV} \mathrm{s}^{-1}$. peak separations of 184, 147 and $321 \mathrm{mV}$ between DA and AA, DA and UA, and UA and AA, respectively, allow us to detect DA, AA and UA simultaneously by using DPV. The value of this separation in peak potential depends on the $\mathrm{pH}$ value of the aqueous solution.

The influence of solution $\mathrm{pH}$ on the electrochemical responses of AA, DA and UA on the modified GCE was investigated by means of differential plus voltammetric method in $0.1 \mathrm{~mol} \mathrm{~L}^{-1}$ buffer solution at various $\mathrm{pH}$ values ranging from 4.0 to 10.0. Further studies show that the oxidation peaks of dopamine and uric acid are separated in all testing $\mathrm{pH}(4.0 \leq \mathrm{pH} \leq 10.0)$ and this separation for ascorbic acid and dopamine is maximum in lower $\mathrm{pH}$ values (Figure S3a), but maximum peak current for the oxidation of ascorbic acid, dopamine and uric acid occurred in the $\mathrm{pH}=8$ (Figure S3b). Therefore, $\mathrm{pH} 8.0$ was selected as an optimum $\mathrm{pH}$ for determination of ascorbic acid, dopamine and uric acid.

The electrocatalytic oxidation potential $\left(\mathrm{E}_{\mathrm{pa}}\right)$ of DA and UA shifted to less positive potential by increasing $\mathrm{pH}$ (Figure S4) with a slope of $-51.0 \mathrm{mV} / \mathrm{pH}$ and $-57.0 \mathrm{mV} / \mathrm{pH}$, respectively, being close to that expected for a monoelectronic/monoprotonic electrode reaction according to Nicholson equation ${ }^{42}\left(-59.2 \mathrm{mV} / \mathrm{pH}\right.$ at $\left.25^{\circ} \mathrm{C}\right)$. As DA and UA oxidation is a two-electron process, the number of protons involved is also predicted to be two. These accord with the mechanism of DA and UA oxidation (Scheme 2) as previously reported. ${ }^{43}$ The influence of the solution $\mathrm{pH}$ in the electrochemical response of AA on the modified GCE showed that there is a linear relationship between electrocatalytic oxidation potential of AA and $\mathrm{pH}$ with the slop $-33 \mathrm{mV} / \mathrm{pH}$. This is expected for a dielectronic/monoprotonic electrode reaction and this accords with the mechanism of AA oxidation (Scheme 2), as the main form of $\mathrm{AA}\left(\mathrm{pK}_{\mathrm{a} 1}=4.7\right)$ is $\mathrm{HA}^{-}$in this $\mathrm{pH}$ range.

Since differential pulse voltammetry has a much higher current sensitivity and better resolution than cyclic voltammetry, it was used in determination of AA, DA and UA concentration on the modified GCE and estimating the lower limit of detection. The oxidation peak currents of AA, DA and UA were measured in $0.10 \mathrm{~mol} \mathrm{~L}^{-1} \mathrm{pH}$ 8.0 PBS, and plotted against the bulk concentration of AA, DA and UA (Figure S5). The linear ranges for the determination of AA, DA, and UA using DPV were $2.70 \times 10^{-5}-1.83 \times 10^{-3}$, $8.33 \times 10^{-7}-1.00 \times 10^{-5}$ and $4.16 \times 10^{-6}-2.25 \times 10^{-4} \mathrm{~mol} \mathrm{~L}^{-1}$, respectively. The theoretical limits of detection defined as $3 \mathrm{~s}$ of the proposed method for AA, DA and UA were $5.00 \times 10^{-6}, 4.16 \times 10^{-8}$ and $7.00 \times 10^{-7} \mathrm{~mol} \mathrm{~L}^{-1}$, respectively. The relative standard deviations of 10 successive scans are $1.2,1.4$ and $1.3 \%$ for $1.0 \mathrm{mmol} \mathrm{L}^{-1} \mathrm{AA}, 30 \mu \mathrm{mol} \mathrm{L}-1$ DA and $90 \mu \mathrm{mol} \mathrm{L}^{-1} \mathrm{UA}$. The reproducibility of five different electrodes was completed. The relative standard deviations 
(a)<smiles>O=C1OC(C(O)CO)C([O-])=C1O</smiles><smiles>O=C1C(=O)C(C(O)CO)OC1=[In+]</smiles>

(b)<smiles>NCCC1=CC(=O)C(=O)C=C1</smiles>

(c)<smiles>O=C1N=C2NC(=O)N=C2C(=O)N1</smiles>

Scheme 2. Mechanism of (a) AA, (b) DA and (c) UA oxidation at the modified GCE.

are 3.4, 3.9 and $4.5 \%$ for $1.0 \mathrm{mmol} \mathrm{L}^{-1} \mathrm{AA}, 30 \mu \mathrm{mol} \mathrm{L} \mathrm{L}^{-1}$ DA and $90 \mu \mathrm{mol} \mathrm{L}^{-1} \mathrm{UA}$, respectively, which indicate that the modified GCE had an excellent reproducibility.

Table 1 shows a comparison between previously reported modified electrodes for determination of AA,
DA and UA and the poly(2,6-DAP)/MWNTs modified GC electrode. As can be seen, the proposed modified electrode shows somewhat similar (or worse) performances (in some cases) or superior ones (in most cases) than the previously reported modified electrodes.

Table 1. Comparison of analytical parameters of several modified electrodes for AA, DA and UA determination

\begin{tabular}{|c|c|c|c|c|c|c|}
\hline Electrode & Method & Analyte & $\begin{array}{l}\text { Linear range / } \\
(\mu \mathrm{mol} \mathrm{L}-1)\end{array}$ & $\begin{array}{l}\text { Limit of } \\
\text { detection / } \\
\left(\mu \mathrm{mol} \mathrm{L}^{-1}\right)\end{array}$ & $\begin{array}{l}\text { Sensitivity / } \\
\left(\mu \mathrm{A} \mu \mathrm{mol}^{-1} \mathrm{~L}\right)\end{array}$ & Reference \\
\hline \multirow{3}{*}{$\begin{array}{l}\text { Modified carbon paste electrode by } \\
\text { tetrabromo- } p \text { benzoquinone }\end{array}$} & \multirow[t]{3}{*}{ DPV } & AA & $10-600$ & 0.62 & 0.005 & \multirow[t]{3}{*}{44} \\
\hline & & DA & $10-100$ & - & 0.0074 & \\
\hline & & UA & $10-100$ & - & 0.0022 & \\
\hline \multirow[t]{3}{*}{ Oxidation in mild acidic media } & \multirow[t]{3}{*}{$\mathrm{CV}$} & AA & $197-988$ & - & - & \multirow[t]{3}{*}{46} \\
\hline & & DA & $1.97-9.78$ & - & - & \\
\hline & & UA & $19.7-97.8$ & - & - & \\
\hline \multirow[t]{3}{*}{ Iron(II)-complex / MWNTs/GC } & \multirow[t]{3}{*}{ DPV } & AA & $11-1500$ & 8 & 0.0118 & \multirow[t]{3}{*}{35} \\
\hline & & DA & $0.9-12000$ & 0.2 & 0.059 & \\
\hline & & UA & $2-1500$ & 1 & 0.0027 & \\
\hline \multirow[t]{2}{*}{$\mathrm{Pt} / \mathrm{PF} / \mathrm{Pd}$ nano } & \multirow[t]{2}{*}{ DPV } & $\mathrm{AA}$ in presence of $\mathrm{ACOP}$ & $50-1000$ & 7.1 & 5.92 & \multirow[t]{2}{*}{50} \\
\hline & & DA in presence of ACOP & $0.5-100$ & 0.5 & 0.0213 & \\
\hline \multirow[t]{3}{*}{$\mathrm{CPE} / \mathrm{CNF} / \mathrm{Pd}$ nano } & \multirow[t]{3}{*}{ DPV } & $\mathrm{AA}$ & $50-4000$ & 15 & - & \multirow[t]{3}{*}{49} \\
\hline & & DA & $0.5-160$ & 0.2 & - & \\
\hline & & UA & $2-200$ & 0.7 & - & \\
\hline \multirow{3}{*}{$\begin{array}{l}\text { Poly (3-(5-chloro-2-hydroxyphenylazo)- } \\
\text { 4,5dihydroxy naphthalene-2,7-disulfonic } \\
\text { acid) film }\end{array}$} & \multirow[t]{3}{*}{ DPV } & AA & $5-240$ & 1.43 & 0.013 & \multirow[t]{3}{*}{45} \\
\hline & & DA & $5-280$ & 2.9 & 0.0157 & \\
\hline & & UA & $0.1-180$ & 0.16 & 0.353 & \\
\hline \multirow{2}{*}{$\begin{array}{l}\text { Novel choline and acetylcholine modified } \\
\text { glassy carbon }\end{array}$} & \multirow[t]{2}{*}{ DPV } & AA & $7-90$ & 0.9 & - & \multirow[t]{2}{*}{48} \\
\hline & & DA & $0.7-5$ & 0.3 & - & \\
\hline \multirow{3}{*}{ Dopamine solutions-phosphate buffer } & \multirow[t]{3}{*}{ DPV } & AA & $25-500$ & 13 & 0.007 & \multirow[t]{3}{*}{47} \\
\hline & & DA & $1-20$ & 0.11 & 0.006 & \\
\hline & & UA & $2.5-20$ & 1.4 & 0.09 & \\
\hline \multirow[t]{3}{*}{ Poly(2, 6-DAP) film ${ }^{a} / M W N T s / G C$} & \multirow[t]{3}{*}{ DPV } & AA & $27-1830$ & 5.0 & - & \multirow[t]{3}{*}{ this work } \\
\hline & & DA & $0.83-10.0$ & 0.0416 & - & \\
\hline & & UA & $4.16-225$ & 0.7 & - & \\
\hline
\end{tabular}

aPoly (2,6-diaminopyridine). 


\section{Interferences}

For investigating the interferences, several compounds were selected. If the tolerance limit was taken as the maximum concentration of the foreign substances, which causes an approximately $5 \%$ relative error for $0.1 \mathrm{mmol} \mathrm{L}^{-1}$ AA, $25.0 \mu \mathrm{mol} \mathrm{L}^{-1} \mathrm{DA}$ and $25.0 \mu \mathrm{mol} \mathrm{L}{ }^{-1} \mathrm{UA}$, no interference was observed for the following compounds $\left(\mu \mathrm{mol} \mathrm{L} \mathrm{L}^{-1}\right): \mathrm{K}^{+}$, $\mathrm{Ca}^{2+}, \mathrm{Mg}^{2+}, \mathrm{Zn}^{2+}$, starch, glutamic acid, tartaric acid and glucose. The results are listed in Table 2.

Table 2. Interferences of some foreign substances for $0.1 \mathrm{mmol} \mathrm{L}^{-1} \mathrm{AA}$, $25.0 \mu \mathrm{mol} \mathrm{L}{ }^{-1} \mathrm{DA}$ and $25.0 \mu \mathrm{mol} \mathrm{L}-1 \mathrm{UA}$

\begin{tabular}{lc}
\hline Foreign substances & Tolerance level $/\left(\mu \mathrm{mol} \mathrm{L}^{-1}\right)$ \\
\hline Tartaric acid & 300 \\
$\mathrm{~K}^{+}, \mathrm{Mg}^{2+}, \mathrm{Ca}^{2+}, \mathrm{Zn}^{2+}$ & 250 \\
Citric acid & 10 \\
Glutamic acid & 250 \\
Glucose & 2500 \\
\hline
\end{tabular}

Determination of $A A$ in vitamin $C$ injection, DA in dopamine hydrochloride injection solutions and UA in well water

In order to demonstrate the capability of this modified electrode for the catalytic oxidation of ascorbic acid, dopamine and uric acid in real samples, it was examined this ability in the voltammetric determination of AA and DA in some pharmaceutical preparation, such as vitamin C injection solution (standard content $100 \mathrm{mg}$ per mL AA, $5 \mathrm{~mL}$ per injection) (Daro Pakhsh Co.) and dopamine hydrochloride injection (DHI) solution (standard content of $40 \mathrm{mg}$ per mL DA, $5 \mathrm{~mL}$ per injection) (Rasht Co.). The proposed modified electrode was also successfully applied to the determination of UA in spiked solution. Several spiked samples were prepared by adding aliquots of UA solution to Koshkan (a village near to Zanjan City in Iran) well water. All samples were diluted with phosphate buffer solution $(\mathrm{pH} \mathrm{8.0)}$ and then appropriate amounts of these diluted samples were transferred to the electrochemical cell to determine each species using DPV.

The standard addition technique was employed for AA, DA and UA determination. The results of AA, DA and UA determinations in the real samples and spiked samples with AA, DA or UA standard solutions are shown in Table 3. The recovery and precision were acceptable, revealing that the modified electrode could be efficiently applied for the determination of AA, DA and UA in pharmaceutical samples.

\section{Conclusions}

In this work, the advantageous features of polymerized film of 2,6-diaminopyridine (2,6-DAP) are demonstrated as electron transfer mediator onto a GC electrode surface. Due to the chemical stability, electrochemical reversibility and high electron transfer rate constant of the modified GCE, it can be used in electrocatalysis as electron transfer mediators to shuttle electrons between analytes and substrate electrodes. The modified electrodes showed excellent electrocatalytic ability for the oxidation of ascorbic acid, dopamine and uric acid. The ternary mixture of them can be well separated from each other at the surface of this modified GCE. Differential pulse voltammetry at the

Table 3. Recovery results obtained for determination of AA, DA and UA and the spiked of them in injection solutions $(n=5)$

\begin{tabular}{|c|c|c|c|c|}
\hline $\begin{array}{l}\text { AA labeled concentration / } \\
\left(\mathrm{mmol} \mathrm{L}^{-1}\right)\end{array}$ & $\begin{array}{l}\text { Added concentration / } \\
\left(\mathrm{mmol} \mathrm{L}^{-1}\right)\end{array}$ & $\begin{array}{l}\text { AA found / } \\
\left(\mathrm{mmol} \mathrm{L}^{-1}\right)^{\mathrm{a}}\end{array}$ & Recovery / \% & $\mathrm{RSD} / \%$ \\
\hline 0.00 & & $0.391 \pm 0.013$ & 97.92 & 1.81 \\
\hline 0.60 & & $0.998 \pm 0.014$ & 99.85 & 1.18 \\
\hline 0.40 & 1.20 & $1.578 \pm 0.02$ & 98.64 & 1.17 \\
\hline 1.80 & & $2.148 \pm 0.02$ & 97.60 & 2.25 \\
\hline $\begin{array}{l}\text { DA labeled concentration / } \\
\qquad\left(\mathrm{mmol} \mathrm{L}^{-1}\right)\end{array}$ & $\begin{array}{l}\text { Added concentration / } \\
\qquad\left(\mathrm{mmol} \mathrm{L}^{-1}\right)\end{array}$ & $\begin{array}{l}\text { DA found / } \\
\left(\mathrm{mmol} \mathrm{L}^{-1}\right)^{\mathrm{a}}\end{array}$ & Recovery / \% & $\mathrm{RSD} / \%$ \\
\hline 0.00 & & 3.81 & 100.26 & 0.92 \\
\hline 3.80 & 1.70 & 5.49 & 99.82 & 1.97 \\
\hline 3.80 & & 7.16 & 99.44 & 1.71 \\
\hline 5.50 & & 8.77 & 99.66 & 1.42 \\
\hline $\begin{array}{l}\text { UA labeled concentration / } \\
\qquad\left(\mathrm{mmol} \mathrm{L}^{-1}\right)\end{array}$ & $\begin{array}{l}\text { Added concentration / } \\
\left(\mathrm{mmol} \mathrm{L}^{-1}\right)\end{array}$ & $\begin{array}{l}\text { UA found / } \\
\left(\mathrm{mmol} \mathrm{L}^{-1}\right)^{\mathrm{a}}\end{array}$ & Recovery / \% & $\mathrm{RSD} / \%$ \\
\hline 12.0 & & 11.98 & 99.06 & 2.27 \\
\hline- & 30.0 & 29.78 & 99.28 & 1.27 \\
\hline 50.0 & & 49.42 & 98.83 & 1.81 \\
\hline
\end{tabular}

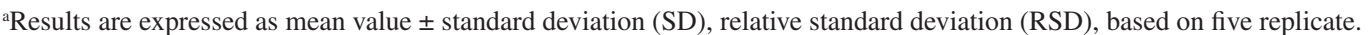


modified GCE allows sensitive and selective determination of these biological compounds in the presence of common interferences in an aqueous solution.

\section{Supplementary Information}

Supplementary data are available free of charge at http://jbcs.sbq.org.br as PDF file.

\section{Acknowledgement}

The authors wish to express their gratitude to the Zanjan University Research Council for the support of this work.

\section{References}

1. Wang, J.; Electroanalysis 1991, 3, 255.

2. Ohnuki, Y.; Ohsaka, T.; Matsuda, H.; Oyama, N.; J. Electroanal. Chem. 1983, 158, 55.

3. Volkov, A.; Tourillon, G.; Lacaze, P. C.; Dubois, J. E.; J. Electroanal. Chem. 1980, 115, 279.

4. Chung, T. D.; Biosens. Bioelectron. 2001, 16, 1079.

5. Trojanowicz, M.; Microchim. Acta 2003, 143, 75.

6. Vidal, J.-C.; Microchim. Acta 2003, 143, 93.

7. Gerard, M.; Chaubey, A.; Malhotra, B.; Biosens. Bioelectron. 2002, 17, 345.

8. Saxena, V.; Malhotra, B. D.; Curr. Appl. Phys. 2003, 3, 293.

9. Malitesta, C.; Palmisano, F.; Torsi, L.; Zambonin, P. G.; Anal. Chem. 1990, 62, 2735.

10. Centonze, D.; Guerrieri, A.; Malitesta, C.; Palmisano, F.; Zambonin, P. G.; Fresenius J. Anal. Chem. 1992, 342, 729.

11. Bartlett, P. N.; Caruana, D. J.; Analyst 1992, 117, 1287.

12. Groom, C. A.; Luong, J. H. T.; Anal. Lett. 1993, 26, 1383.

13. Lowry, J. P.; McAteer, K.; El Atrash, S. S.; Duff, A.; O’Neill, R. D.; Anal. Chem. 1994, 66, 1754.

14. Palmisano, F.; Guerrieri, A.; Quinto, M.; Zambonin, P. G.; Anal. Chem. 1995, 61, 1005.

15. Santhosh, P.; Gopalan, A.; Vasudevan, T.; Lee, K. P.; Appl. Surf. Sci. 2006, 252, 7964.

16. Golabi, S. M.; Nozad, A.; Electroanalysis 2003, 15, 278.

17. Nozad, A. G.; Golabi, S. M.; Maragheh, M. G.; Irannejad, L.; J. Power Sources 2005, 145, 116.

18. Pournaghi-Azar, M. H.; Habibi, B.; J. Electroanal. Chem. 2007, $601,53$.

19. Jang, D.-H.; Bull. Korean Chem. Soc. 1995, 16, 392.

20. Martinusz, K.; Láng, G.; Inzelt, G.; J. Electroanal. Chem. 1997, $433,1$.

21. Somasundrum, M.; Aoki, K.; J. Electroanal. Chem. 2002, 530, 40.

22. Griffith, A.; Glidle, A.; Cooper, J. M.; Biosens. Bioelectron. 1996, 11, 625 .

23. Yao, T.; Anal. Sci. 2003, 19, 61.
24. Liu, A.; Honma, I.; Zhou, H.; Biosens. Bioelectron. 2007, 23 , 74.

25. Lin, X.; Zhuang, Q.; Chen, J.; Zhang, S.; Zheng, Y.; Sens. Actuators, B: Chemical 2007, 125, 240.

26. Ozcan, L.; Sahin, M.; Sahin, Y.; Sensors 2008, 8, 5792.

27. Yao, H.; Suna, Y.; Lin, X.; Tang, Y.; Huang, L.; Electrochim. Acta 2007, 52, 6165.

28. Gopalan, A. I.; Lee, K.-P.; Manesha, K. M.; Santhosh, P.; Kim, J. H.; Kang, J. S.; Talanta 2007, 71, 1774.

29. Zare, H. R.; Nasirizadeh, N.; Ardakani, M. M.; J. Electroanal. Chem. 2005, 577, 25.

30. Lin, L.; Chen, J.; Yao, H.; Chen, Y.; Zheng, Y.; Lin, X.; Bioelectrochemistry 2008, 73, 11.

31. Sudhakara Prasad, K.; Muthuraman, G.; Zen, J.-M.; Electrochem. Commun. 2008, 10, 559.

32. Lin, X.; Zhuang, Q.; Chen, J.; Zhang, Sh.; Zheng, Y.; Sens. Actuators, B: Chemical 2007, 125, 240.

33. Yao, H.; Sun, Y.; Lin, X.; Tang, Y.; Huang, L.; Electrochim. Acta 2007, 52, 6165.

34. Jiao, Sh.; Li, M.; Wang, C.; Chena, D.; Fang, B.; Electrochim. Acta 2007, 52, 5939.

35. Kamyabi, M. A.; Narimani, O.; Monfared, H. H.; J. Braz. Chem. Soc. 2011, 22, 468.

36. Morea, G.; Guerrieri, A.; Malitesta, C.; Torsi, L.; J. Chem. Soc., Faraday Trans. 1991, 87, 3515.

37. Kamyabi, M. A.; Narimani, O.; Monfared, H. H.; J. Electroanal. Chem. 2010, 642, 67.

38. Dai, H. P.; Wu, Q. H.; Sun, S. G.; Shiu, K. K.; J. Electroanal. Chem. 1998, 456, 47.

39. Yu, B.; Khoo, S. B.; Electrochim. Acta 2005, 50, 1917.

40. Bacon, J.; Adams, R. N.; J. Am. Chem. Soc. 1968, 90, 6596.

41. Bilal, S.; Holze, R.; J. Electroanal. Chem. 2006, 592, 1.

42. Nicholson, R. S.; Anal. Chem. 1965, 37, 1351.

43. Zhao, Y.; Gao, Y.; Zhan, D.; Hui, H.; Zhao, Q.; Kou, Y.; Shao, Y.; Li, M.; Zhuang, Q.; Zhu, Z.; Talanta 2005, 66, 51.

44. Kalimuthu, P.; John, S. A.; Bioelectrochemistry 2009, 77, 13.

45. Poh, W. C.; Loh, K. P.; Zhang, W. D.; Triparthy, S.; Ye, J. S.; Shen, F. S.; Langmuir 2004, 20, 5484.

46. Antiochia, R.; Lvagnini, I.; Magno, F.; Valentini, F.; Palleschi, G.; Electroanalysis 2004, 16, 1451.

47. Wang, J. X.; Li, M. X.; Shi, Z. J.; Li, N. Q.; Gu, Z. N.; Anal. Chem. 2002, 74, 1993.

48. Wang, L.; Wang, J. X.; Zhou, F. M.; Electroanalysis 2004, 16, 627.

49. Wang, J.; Peng, T.; Vince, V.; J. Electroanal. Chem. 1987, 234, 119.

50. Fei, J.; Wu, K.; Yi, L.; Li, J.; Bull. Korean Chem. Soc. 2005, 26, 1403.

Submitted: April 10, 201

Published online: February 2, 2012 